Discussion Paper No. 05-64

Exchange Rate or Wage Changes in International Adjustment?

Japan and China versus the United States

Ronald McKinnon

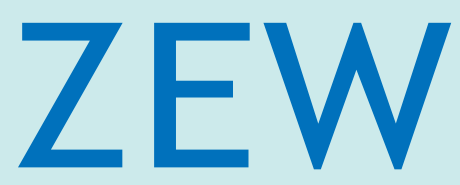

Zentrum für Europäische Wirtschaftsforschung $\mathrm{GmbH}$

Centre for European

Economic Research 
Discussion Paper No. 05-64

\title{
Exchange Rate or Wage Changes in International Adjustment? Japan and China versus the United States
}

\author{
Ronald McKinnon
}

Download this ZEW Discussion Paper from our ftp server:

ftp://ftp.zew.de/pub/zew-docs/dp/dp0564.pdf

Die Discussion Papers dienen einer möglichst schnellen Verbreitung von neueren Forschungsarbeiten des ZEW. Die Beiträge liegen in alleiniger Verantwortung der Autoren und stellen nicht notwendigerweise die Meinung des ZEW dar.

Discussion Papers are intended to make results of ZEW research promptly available to other economists in order to encourage discussion and suggestions for revisions. The authors are solely responsible for the contents which do not necessarily represent the opinion of the ZEW. 


\section{Non-Technical Summary}

A reading of the recent financial press suggests that a major depreciation of the dollar is needed to correct the current account and trade deficits of the United States which are believed to be unsustainable. For this purpose, East Asia countries stop pegging their currency to the dollar. Especially China should allow a large appreciation of the renminbi and afterwards move to unrestricted floating.

This argumentation rests on two crucial assumptions. The first assumption is that an appreciation of the Asian currencies against the dollar would significantly reduce the trade surplus of the countries with the United States. The second is that a more flexible exchange rate is needed to fairly balance international competitiveness.

In the paper, I show that these assumptions do not hold under a regime of the international dollar standard. In this case, a discrete appreciation by a dollar creditor country of the United States would have no predictable effect on its trade surplus. The assumption of a reduced trade surplus only takes into account the relative price effects but does neglect the income (absorption) effect which is not small and controllable under a dollar standard. Moreover, a differential adjustment in the rate of growth of money wages will more accurately reflect international differences in productivity growth, when a peripheral country's dollar exchange rate is fixed.

For China, the paper proposes a move towards a very narrow band for the yuan/dollar exchange rate. This would decentralize foreign exchange transacting but not significantly affect China's competitiveness in international markets for goods or services. A high growth in domestic money wages that reflects a very high growth in labor productivity would remain the dominant mechanism for balancing international competitiveness. 


\title{
Exchange Rate or Wage Changes in International Adjustment? Japan and China versus the United States
}

\author{
Ronald McKinnon ${ }^{1}$ \\ Stanford University
}

May 2005

\begin{abstract}
Under the world dollar standard, a discrete appreciation by a dollar creditor country of the United States, such as China or Japan, has no predictable effect on its trade surplus. Currency appreciation by the creditor country will slow its economic growth and eventually cause deflation but cannot compensate for a savinginvestment imbalance in the United States. Under a fixed exchange rate, however, differential adjustment in the rate of growth of money wages will more accurately reflect international differences in productivity growth. International competitiveness will be better balanced between high-growth and low-growth economies, as between Japan and the U.S. from in 1950 to 1971 and China and the U.S. from 1994 to 2005, when the peripheral country's dollar exchange rate is fixed so that its wage growth better reflects its higher productivity growth. The qualified case for China moving toward greater flexibility in the form of a very narrow band for the yuan/dollar exchange rate, as a way of decentralizing foreign exchange transacting, is discussed.
\end{abstract}

Acknowledgement: The author would like to thank Hong Qiao and Ricardo Fernholz of Stanford University, and Gunther Schnabl of the University of Tubingen, for their great help in preparing this paper as well as all participants of the ZEW Summer Workshop for helpful comments and suggestions.

JEL-Classification: F15, F 31, and F33

Keywords: exchange rate, dollar standard, trade balance, China, Japan

1 Economics Department, Stanford University, Stanford, California 94305 e-mail: Mckinnon@stanford.edu, Fax: (650) 725 5702, Tel (650) 7233721 


\section{Introduction}

Seldom have the pages of the financial press in Europe and America been so full of grave editorializing on the need for a major depreciation of the dollar to correct the "unsustainable" current account and trade deficits of the United States. Much of this international moralizing directs the high-growth East Asian countries to stop pegging their currencies to the dollar-or, in China's case, to allow a large appreciation of the renminbi before moving to unrestricted floating. The critics' message has two facets.

First, in order to reduce East Asia's large trade surpluses and thereby reduce America's even larger trade deficit, U.S. and European critics suggest that Asian governments should let their currencies appreciate discretely against the dollar. For example, Fred Bergsten, Morris Goldstein, Nicholas Lardy, and Michael Mussa from the Institute for International Economics (IIE) in Washington D.C., all suggest that an immediate 20 to 25 percent appreciation of the renminbi is warranted (Bergsten et al. 2005). However, they provide no suitable conceptual model-let alone econometric evidence - that this would significantly reduce China's trade surplus with the United States.

Second, because of the very high ongoing productivity growth in some East Asian countries (notably China) relative to that in the United States and Europe, critics contend that subsequent continual appreciation of the renminbi (couched in terms of making its exchange rate more flexible) may also be required to fairly balance international competitiveness. And many outside critics see "smooth" ongoing upward adjustments in the renminbi to be best obtained by China's government eventually allowing its currency to float freely-instead of intervening heavily to hold it down as is now the case.

In this paper, I contend that these critics are wrong in both respects. Their "conventional wisdom" is based on faulty, although unfortunately widely accepted, theorizing that fails to come to grips with how the international dollar standard works.

I will first discuss why a discrete appreciation by a dollar creditor country of the United States such as China or Japan would have no predictable effect on its trade surplus. I will then show how differential adjustment in the rate of growth of money wages will more accurately reflect international differences in productivity growth, i.e., international competitiveness will be better balanced through time, when a peripheral country's dollar exchange rate is fixed. Finally, I will discuss the optimal degree of flexibility in the foreign exchanges for China at the present time. 


\section{The Exchange Rate and the Trade Balance}

Why is the common presumption that an exchange rate change by itself would have a predictable effect on a country's trade balance often incorrect? This presumption has been canonized in a model called the elasticities approach to the balance of trade that focuses on relative price effects. It is intuitively plausible because an appreciating country's exports obviously become more expensive in world markets and fall, whereas imports become cheaper and "should" increase. The problem is that proponents of the elasticities approach focus on these relative price effects of an exchange rate change and either ignore the income (absorption) effects or believe them to be small and controllable.

But under the world dollar standard where foreign trade and asset flows are largely invoiced in dollars, a peripheral country will be exposed to major income and wealth effects should its dollar exchange rate change. In particular, an appreciation against the dollar would have (is having) unacceptable worldwide macroeconomic consequences without correcting the U.S. trade and current account deficits.

Among financially open economies, sustained exchange rate changes must reflect relative monetary policies expected in the future: relatively tight money and deflation in the appreciating countries and relatively easy money with inflation in the country whose currency depreciates. After a sharp appreciation, multinational as well as national firms will see the country as a less good (more expensive) place in which to invest so that investment slumps. In creditor countries that have built up large dollar claims on foreigners, this deflationary impact of an exchange appreciation is further accentuated because these dollar assets lose value in terms of the domestic currency: a negative wealth effect that reduces consumption as well as investment. In summary, depressed domestic spending offsets the relative price effect of an appreciation so as to leave the effect on the net trade balance indeterminant. $^{2}$

The high-saving countries in Asia and Europe (and including Canada), all creditors of the low-saving United States, face the specter of a growth slowdown or outright deflation should their currencies appreciate. For example, the repeated appreciations of the yen from 1985 to 1995 created the bubble in Japanese land and equity values from 1987 to 1990 and then, with the inevitable collapse of the bubble, threw Japan into a deflationary slump in the 1990s with a zero interest liquidity trap that made

2 In dollar debtor countries facing the threat of having their currencies depreciate against the dollar, the negative wealth effect tends to reinforce the relative price effect of an actual devaluation. Their trade balances could improve sharply from devaluation as domestic consumption (and imports) slumps even as their now cheaper exports expand into world markets. This was the case for Indonesia, Korea, Malaysia, Philippines, and Thailand after the great Asian crisis of 1997-98. Their current accounts went from being sharply negative before the crisis to positive immediately afterwards. 
monetary policy helpless to revive the Japanese economy. In 2003 and 2004, the Japanese economy staged a partial recovery on the back of the China boom. But the current rise of the yen toward 100 to the dollar could well throw Japan, still in a liquidity trap, into a renewed deflationary slump in 2005. Similarly, with the 50 percent appreciation of the euro against the dollar in 2002-2004, continental Europe is facing slower economic growth-although not yet as protracted as the earlier Japanese experience.

These exchange-rate induced growth slowdowns or slumps in the appreciating economies sharply reduce their demand for imports. At the same time, their exports become more expensive in world markets. Because the fall in exports is coupled with a fall in imports, the net effect on their trade balances is unpredictable (McKinnon and Ohno 1997, chs 6 and 7). The ever-higher yen from 1971 to 1995 led to even bigger Japanese trade surpluses. All that is predictable is that the appreciating country will suffer deflationary pressure. However, if outside commentators and government officials persist in the mistaken belief that appreciation will reduce the trade surpluses of America's creditor countries, their "talk" encourages hot money flows out of dollars into the currencies of creditor countries in Asia and Europe-a particularly acute problem for China currently. These countries then find it more difficult to avoid actual appreciation and unwanted deflation.

Conversely, if deflationary pressure in creditor countries is muted because of orchestrated joint appreciations of their currencies against the dollar, this would induce an outburst of unacceptably high inflation in the United States. For example, President Nixon's well-telegraphed depreciation of the dollar in August 1971 touched off a flight from dollar assets and also the high and volatile U.S. inflation of the 1970s.

If exchange rate changes are not the answer to American trade deficits and Asian trade surpluses, what are the more fundamental causes? The major ongoing and long-run distortion in the world's financial system is America's saving deficiency, large fiscal deficits by the Federal Government and meager household saving, coupled with a virtually unlimited dollar line of credit on to borrow from the rest of the world. ${ }^{3}$ In addition, over the last two years, U.S. monetary policy has also been too loose with short-term interest rates well below the rate of inflation leading to excess consumption - in part by inducing a bubble in housing prices.

3 In a provocative paper, Ben Bernanke (2005) argues that the problem is more one of excess saving in other countries, particularly in Asia, than a saving deficiency in the United States. Either way, however, this international saving imbalance cannot be corrected by exchange rate changes. 
The result is heavy U.S. borrowing in international markets that is then transferred in terms of real resources by foreign countries running trade surpluses with the United States. The U.S. current-account deficit forces Canada and countries in Asia, Europe, and now even in Latin America, into current account surpluses.

\section{The Exchange Rate and International Competitiveness}

At least some of the critics of Asian countries' pegging to the dollar would agree that low saving in the United States, rather than misaligned exchange rates, is the root cause of the trade imbalance. However, suppose a country with very high productivity growth such as China trades with countries with much lower productivity growth. In the new millennium, Japan and Europe have overall trade surpluses, and the United States has an overall trade deficit. But all of these more mature industrial countries have much lower productivity growth than China's. Isn't exchange rate flexibility with ongoing appreciation of the renminbi more or less necessary to balance international competitiveness by offsetting the productivity differential between China and its slower growing trading partners? Indeed, because of foreign unease, China has promised that the yuan/dollar exchange rate will become more flexible in the future.

As long as the American price level remains stable, more flexibility in the central exchange rate of 8.28 yuan per dollar is neither necessary nor desirable for balancing international competitiveness with China's neighbors in the long run. International adjustment occurs by money wages naturally growing faster in the country with higher productivity growth. But this mechanism of differential wage adjustment, with more rapid wage growth in China than the United States, only works well when enterprises and workers in China are confident that the central rate will remain fixed indefinitely, and China's inflation remains more or less aligned with that in the United States. Then Chinese employers in the rapidly growing tradables sectors, largely manufacturing, will vigorously bid for workers subject to the constraint of having to remain internationally competitive at the fixed nominal exchange rate. Money wages, particularly for the increasingly skilled workers, then rise in line with the high-productivity growth. Similar wage growth than spreads out through the rest of the economy, including nontradable services.

In the 1950s and 1960s under the Bretton Woods system of fixed dollar exchange rates, how differential wage growth became the principal mode of international adjustment was first articulated for high-growth Scandinavia when the Swedish, Norwegian, and Danish currencies were all pegged to the dollar. But very high productivity growth in postwar Japan relative to the United States, when the yen/dollar rate was also convincingly fixed, provides an equally striking example of what is now known as the "Scandinavian Model" of wage adjustment (Lindbeck, 1979). 


\section{Japan's Dollar Exchange Rate in Historical Perspective}

When the yen was fixed at 360 to the dollar from 1950 to 1971, the importance of relative wage adjustment between Japan and the United States was pronounced. Table 1 gives the summary statistics for this remarkable era of very high Japanese growth in comparison to those of the wealthier, and consequently more slowly growing, United States. From 1950 to 1971, Japan's annual growth in real output was 9.45 percent while industrial production grew an even more astonishing 14.56 percent per year. Unsurprisingly, the annual growth in Japanese labor productivity of 8.92 percent was far in excess of the 2.55 percent in the United States. However, the balancing item was that average money wages grew at a robust rate of 10 percent per year in Japan and only 4.5 percent in the U.S. Figure 1 shows the dramatic rise of Japanese money wages relative to American wages under the Bretton Woods system of fixed dollar exchange rates.

Table 1: Key economic indicators for Japan and the United States, 1950-1971 (average annual percent change)

\begin{tabular}{|cccccccc|}
\hline Wholesale prices & \multicolumn{2}{c}{ Money wages } & \multicolumn{2}{c}{ Consumer prices } & \multicolumn{2}{c|}{$\begin{array}{c}\text { Industrial } \\
\text { production }\end{array}$} \\
\hline U.S. & Japan & U.S. & Japan & U.S. & Japan & U.S. & Japan \\
\hline 1.63 & $0.69^{\mathrm{a}}$ & 4.52 & 10.00 & 2.53 & 5.01 & 4.40 & 14.56 \\
& & & & & & & \\
\multicolumn{2}{c}{ Real GDP } & \multicolumn{2}{c}{ Nominal GDP } & Narrow money & Labor productivity \\
\hline U.S. & Japan & U.S. & Japan & U.S. & Japan & U.S. & Japan $^{2}$ \\
\hline 3.84 & $9.45^{\mathrm{a}}$ & 6.79 & $14.52^{\mathrm{a}}$ & 3.94 & $16.10^{\mathrm{b}}$ & 2.55 & $8.92^{\mathrm{c}}$ \\
\hline
\end{tabular}

Source: IMF, International Financial Statistics, CD-ROM, October 2003, unless otherwise noted. Japanese real income data, wholesale price data, and labor productivity data are from Japan Economic Yearbook, 1960-1971, Economic Survey of Japan, 1954-1959, and OECD Economic Surveys: Japan, 1964-1971. Labor productivity data for the U.S. are obtained from the index for the nonfarm business sector as reported by the Bureau of Labor Statistics. Note that labor productivity refers to the industrial sector.

a1952-1971.

b1953-1971.

c1951-1971. 
Figure 1: Nominal Manufacturing Wage Growth for US and Japan:

1950-1971

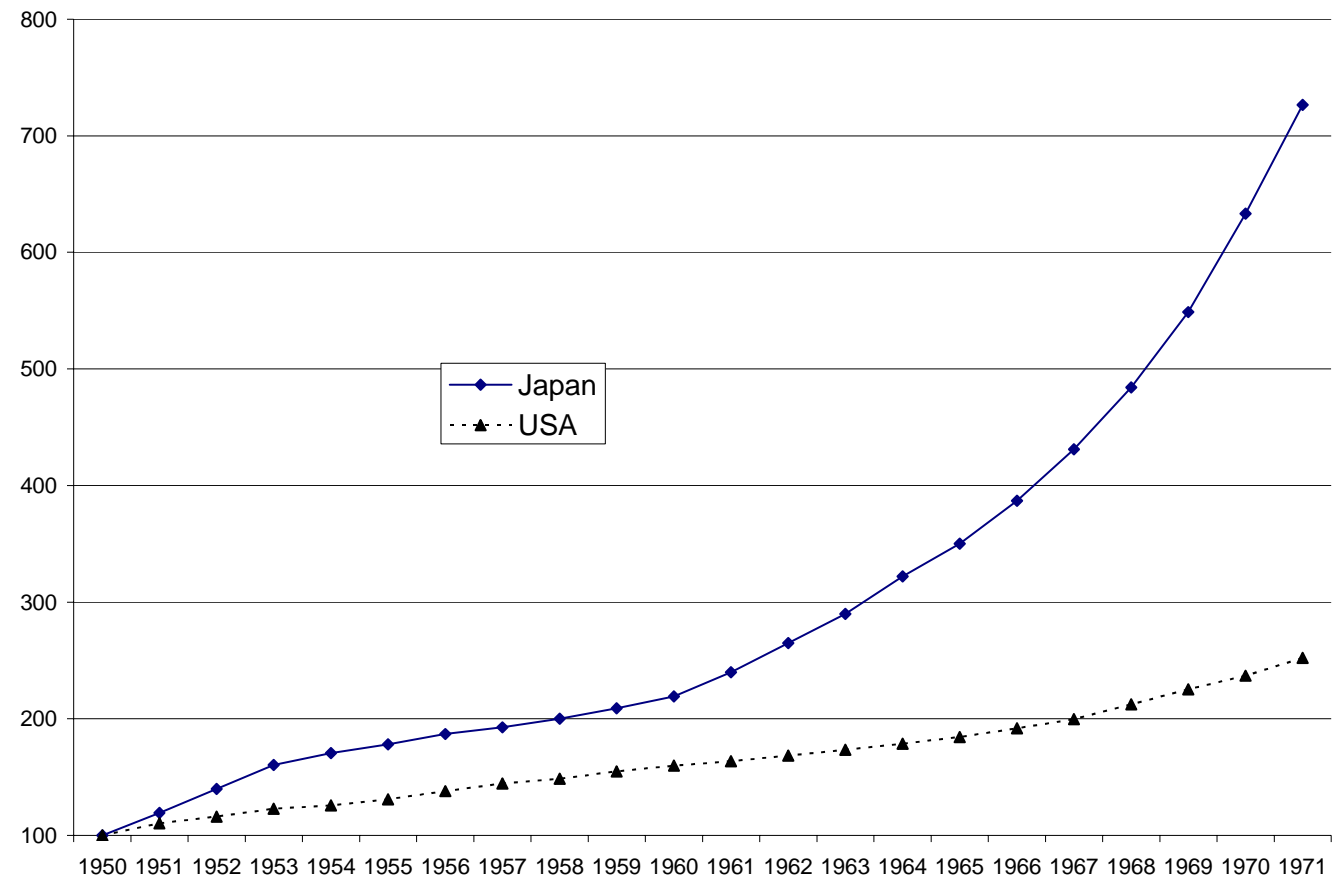

Source: IFS: IMF

Keeping the yen at 360 per dollar effectively anchored Japan's price level for tradable goods. In the 1950s and 1960s, the Japanese wholesale price index (WPI) rose less than 1 percent per year whereas the American WPI rose a bit more than 1 percent (Table 1). Because the bulk of world trade was invoiced in dollars, fixing an exchange rate to the dollar was (is) a stronger anchor for the price level than the size of Japanese bilateral trade with the United States would suggest.

Employers in Japan's manufacturing export sector, with its extremely high growth in labor productivity, then bid vigorously for both skilled and unskilled workers subject to remaining internationally competitive at the fixed exchange rate. Wages rose rapidly in manufacturing so that workers received the main fruits from the productivity growth there. But then, as in the Scandinavian Model, these high wage settlements spread into the rest of the economy, such as nontradable services, where productivity growth was much lower. The result was that, within Japan, the price of services rose relative to goods prices. For 1950-71, Table 1 shows that Japan's CPI, which includes services as well as goods, began to increase much faster at 5 percent per year than its WPI, which contains only goods. But Japan's international competitiveness in its high-growth tradables sector remained balanced with the United States. 
In Japan's bygone high-growth era, fashioning a purely domestic monetary anchor would have been more difficult. As in China today, restrictions on domestic interest rates proliferated; and the rate of growth in narrow money was high and unpredictable-more than 16 percent per year from 1950 to 1971 as Japanese households rebuilt their financial assets after the war. Thus having the Bank of Japan simply key on the dollar exchange rate was the most convenient instrument for stabilizing Japan's tradable goods price level while promoting high growth in money wages.

By the end of the 1960s, however, American monetary policy became too inflationary. The loss of America's foreign competitiveness was too great for the Bretton Woods system of fixed dollar exchange parities to survive. President Nixon had to choose between disinflating at home and thus maintaining the fixed rate system, or forcing a devaluation of the dollar against other major currencies while continuing to inflate. He chose to devalue in August 1971, and the United States suffered the great inflation of the 1970s.

The "Floating" Yen: Appreciation and Deflation. For two decades after August 1971, productivity growth in Japan remained high relative to that in the United States. Japanese exports made major inroads into American markets for steel, autos, machine tools, semi-conductors, and so on. In the midst of numerous trade disputes, the U.S. government reacted by continually trying to "talk" or force the yen up on the presumption that an appreciating yen would improve America's external competitiveness ${ }^{4}$. Indeed, the yen did rise all the way from 360 in 1971 to touch 80 to the dollar in April 1995, and threw Japan into its deflationary slump of the 1990s with a zero interest liquidity trap that lasts to the present day (McKinnon 2005).

The deflation also reduced growth in Japanese money wages. It essentially destroyed the natural wage-adjustment mechanism for balancing international competitiveness that had held when the exchange rate was fixed. Once the yen began to appreciate, Figure 2 shows the breakdown in relative wage adjustment-albeit with a lag. Before 1975, money wage growth in Japan remained much higher than in the United States. Subsequently, as relative deflation in Japan set in (particularly from the sharp rise in the yen in 1977-78), Japan's money wage growth slowed sharply. From the 1980s into the new millennium, it became even lower than that in the United States. So, besides damaging the Japanese economy in a macroeconomic sense while failing to reduce its trade surplus, the erratically appreciating yen undermined the natural process of relative wage adjustment for balancing international competitiveness.

4 As discussed in detail in Chapter 4 of McKinnon and Ohno (1997). 
Figure 2: Inflation and Wage Differential between Japan and US, and Yen/Dollar Rate, 1950 to 2004

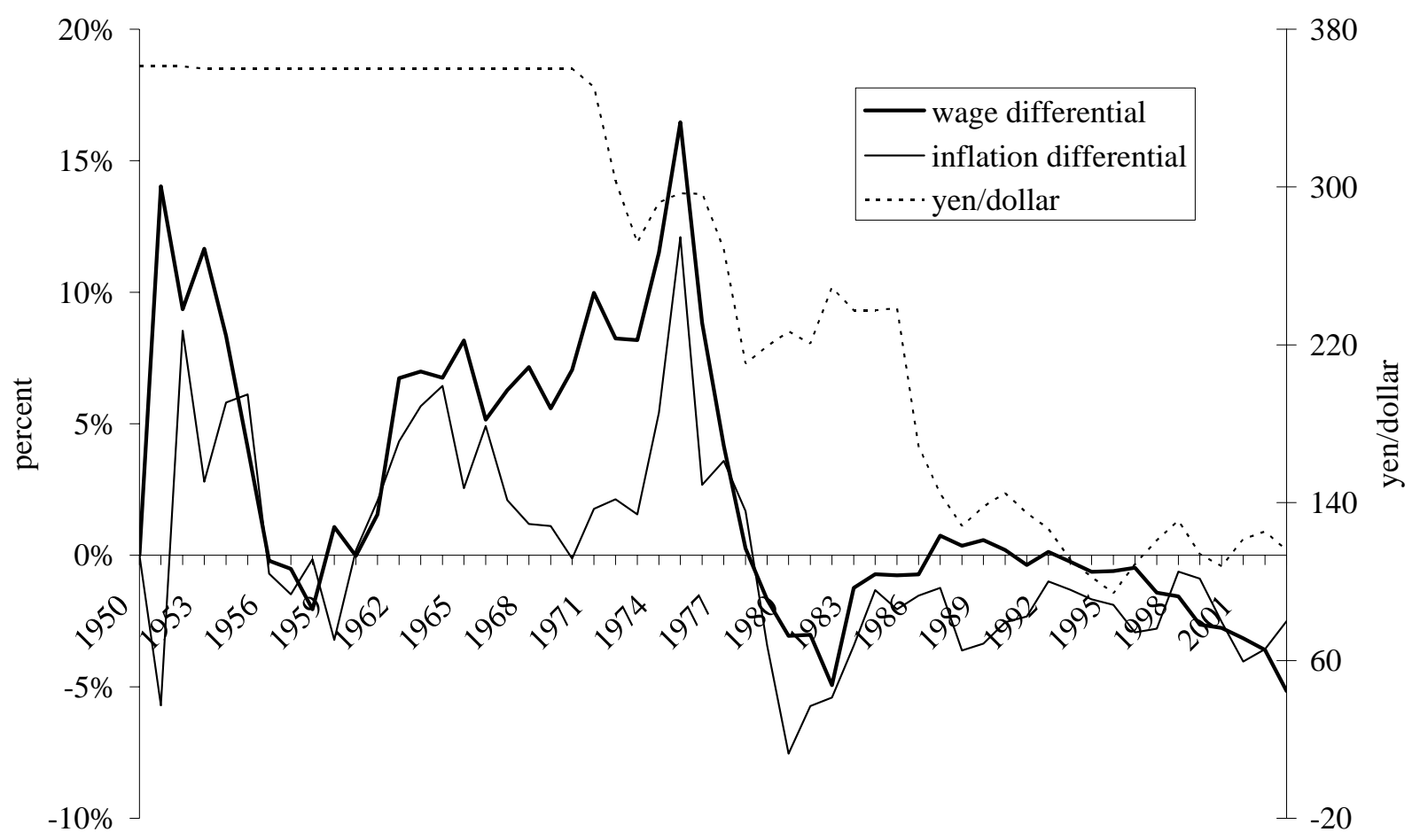

Source: IMF: IFS. Positive values indicate higher inflation and higher wage increases in Japan.

Although the yen has not appreciated on net balance since 1995, it has fluctuated widely against the dollar. Without the assurance of a fixed exchange rate anchor, reestablishing growth in Japanese money wages to accurately reflect (potential) productivity growth remains problematic. In 2004, annual money wage growth in Japan was close to zero whereas in the U.S. it was 2.4 percent.

\section{Wage Adjustment in China under a Fixed Exchange Rate}

Unlike Japan, China has kept its exchange rate stable since 1994—and did not have the earlier misfortune of being pushed into a deflationary slump from an appreciating currency. Table 2 provides the key summary statistics comparing China to the United States. From 1994 through 2003, money wages in manufacturing increased by about 13 percent in China and by just 3 percent in the United States. This 10 percentage-point wage-growth differential approximately reflected the differential growth of labor productivity: about 12.3 percent in China ${ }^{5}$ versus 2.7 percent in the United States since 1994. Under the fixed yuan/dollar exchange rate,

5 This estimate of productivity growth is not official, and was taken from Zhang and Tan (2004). In both countries, how best to measure labor productivity growth is controversial. Estimates for China can vary. 
the appropriate wage-adjustment mechanism for balancing international competitiveness seems to be alive and well.

Table 2: Key economic indicators for China and the United States, 1994-2003 (average annual percent change)

\begin{tabular}{|cccccccc|}
\hline \multicolumn{2}{|c}{} & \multicolumn{2}{c}{$\begin{array}{c}\text { Money wages } \\
\text { (Mfg) }\end{array}$} & \multicolumn{2}{c|}{ Consumer prices } & \multicolumn{2}{c|}{$\begin{array}{c}\text { Industrial } \\
\text { production }\end{array}$} \\
\hline U.S. & China & U.S. & China & U.S. & China & U.S. & China \\
\hline 1.53 & $1.26^{\mathrm{a}}$ & 3.03 & $13.04^{\mathrm{b}}$ & 2.43 & 2.84 & 3.00 & $12.17^{\mathrm{c}}$ \\
& & & & & & & \\
\multicolumn{2}{|c}{ Real GDP } & \multicolumn{2}{c}{ Nominal GDP } & Narrow money & Labor productivity \\
\hline U.S. & China & U.S. & China & U.S. & China & U.S. & China \\
\hline 3.17 & 8.55 & 5.03 & 10.74 & 4.16 & 17.88 & 2.70 & $12.32^{\mathrm{d}}$ \\
& & & & & & & $9.48^{\mathrm{e}}$ \\
\hline
\end{tabular}

Source: IMF, International Financial Statistics. CD-ROM, Nov 2004, unless otherwise noted. Chinese CPI, manufacturing wage data, labor productivity data, real income data, and wholesale price data are from China Statistical Yearbook, 2004. Labor productivity data for the U.S. are obtained from the index for the nonfarm business sector as reported by the Bureau of Labor Statistics. The China labor productivity data refers only to the industrial sector.

${ }^{\text {a }}$ Ex-factory price index.

b 2003 data on manufacturing wages is projected from overall average wages from 1997-2003.

c $1994-2002$.

d 1994-2001. Zhang and Tan

e 1994-2002. R. Fernholz

Figure 3 shows China's dramatically higher growth in money wages in manufacturing relative to the United States over the past decade. Within China, Figure 4 show that wages in all sectors were rising fast-with wage growth in manufacturing about the median for the economy as a whole. Much of this reflects the upgrading of skills and greater work experience of the labor force. True, at the margin, the wages of unskilled migrant workers may be lagging - and many of these seem to be absorbed into construction activities where average wages show the slowest rate of growth in Figure 4. 
Figure 3: Nominal Manufacturing Wage Growth for US and China, 1994-2003 (Base Year $1994=100$ )

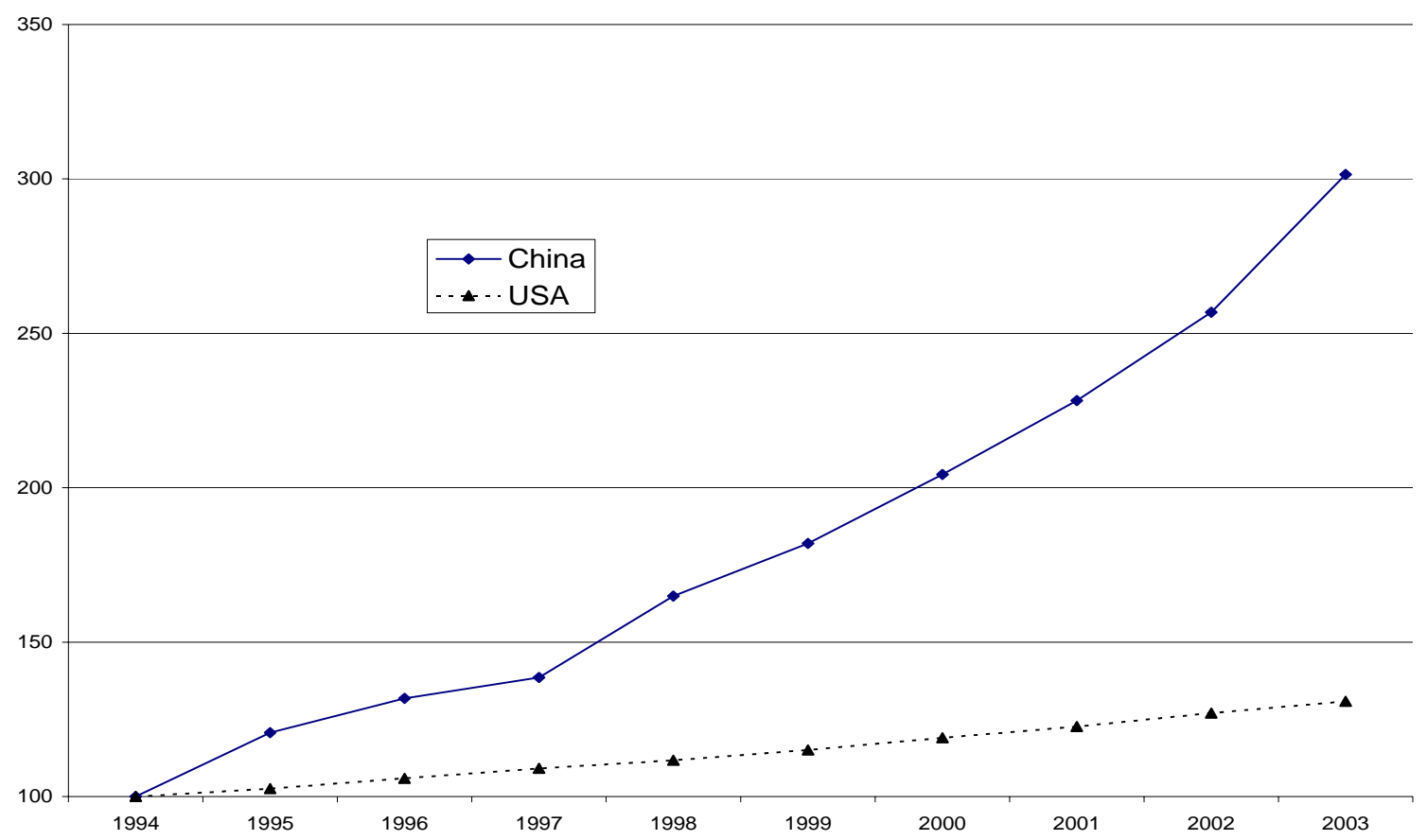

Source: IFS: IMF; Chinese manufacturing wage data are obtained from China Statistical Yearbook, 2004

Figure 4: China: nominal Wages Across Different Sectors, 1994-2002

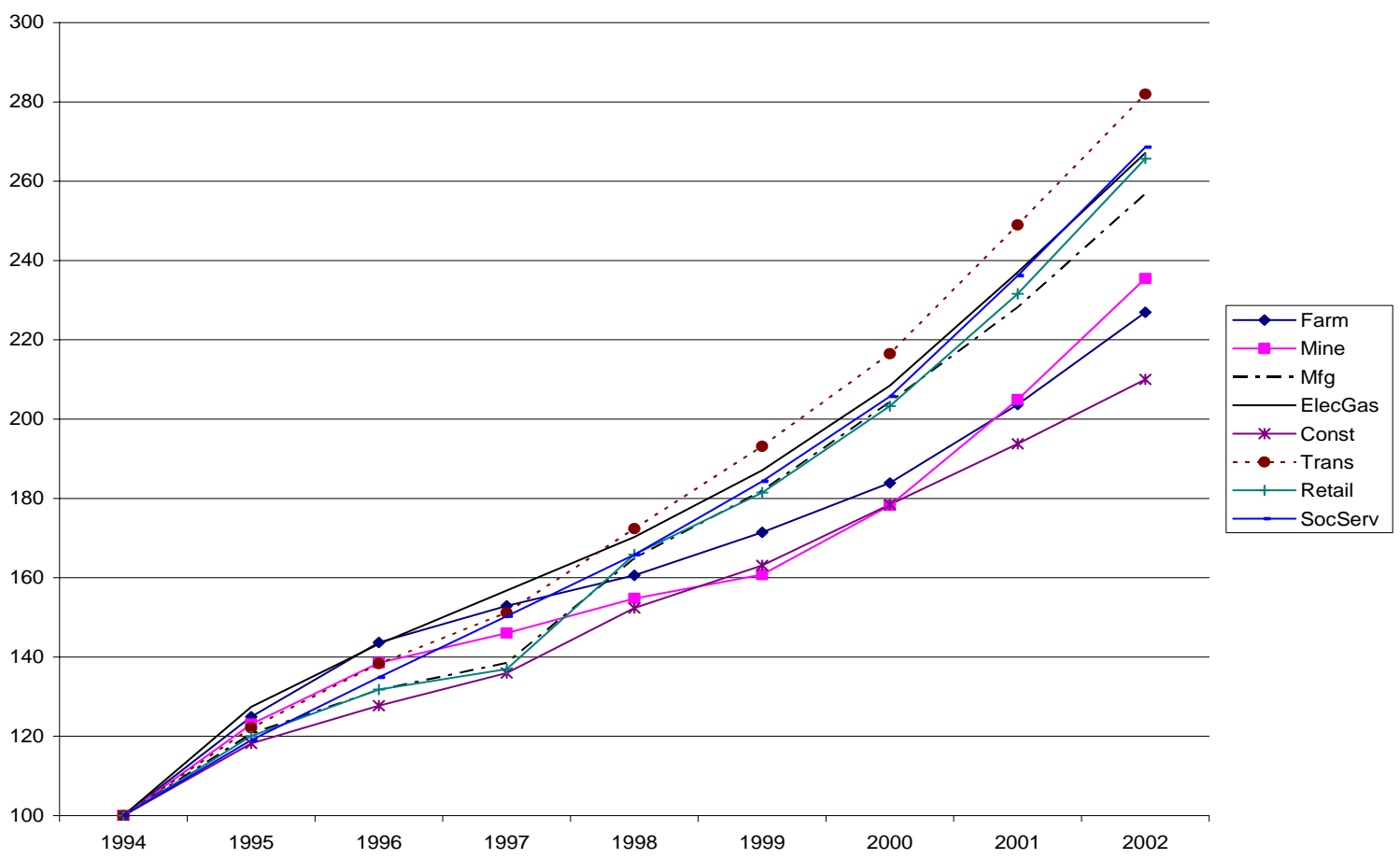

Source: China Statistical Yearbook, 2003 
China's exchange rate stabilization in 1994 followed a major depreciation of the renminbi associated with the unification of the official exchange rate at the much higher "free-market" swap rate. Figure 5 shows that the official rate jumped from 5.5 to 8.7 yuan per dollar. Because much of China's trade-particularly in manufacturers - had been transacted at the higher swap rate, this jump in the official rate overstates the effective devaluation. Nevertheless, because of a temporary burst of domestic inflation from 1993 to 1996 as shown in figures 5 and 6, the "real" devaluation was negligible. But the nominal devaluation certainly exacerbated the inflation. By 1996, the renminbi had appreciated slightly to 8.28 to the dollar where it has remained ever since. Chinese price inflation then settled down after 1996 and seems have converged close to the American level. In 2004, the China's CPI rose 3.8 percent while that in the United States rose 3.3 percent. The fixed rate regime now serves China as a nominal anchor for its price level much like the fixed yen/dollar rate served Japan in the 1950s and 1960s.

One might argue that, in 2004, inflation was too high in both China and the United States. But under the international dollar standard, only the center country can exercise monetary policy independently. Thus the onus is on the United States to disinflate. Fortunately, in 2005, the Federal Reserve seems to be committed to steadily increasing short-term interest rates back to more normal levels after its unprecedented monetary easing (low federal funds rates) in 2003 and 2004. Thus, in 2005, inflation should calm down in both countries. China should have less trouble with inflows of "hot" money, and even less trouble if outside commentators and government officials stop talking about the "need" to appreciate the RMB.

More generally for the increasingly integrated East Asian economies, China's fix at 8.28 yuan per dollar has become the key to intra East Asian exchange stability in the new millennium. All the others more or less peg to the dollar and thus to each other. If this fixed rate system continues, adjustment in relative wage growth in the other East Asian economies becomes the main vehicle for balancing international competitiveness.

In the context of the old Scandinavian model of wage adjustment, the tableau below compares the 1950-71 Japanese and 1994-2005 Chinese experiences under fixed dollar exchange rates (the first row) with the post 1971 Japanese experience with a floating and erratically appreciating yen (the second row). 
Tableau on Wage Bargaining

\begin{tabular}{|c|c|c|c|}
\hline & Relative PPP & Wage Bargaining Process & Money Wage Growth \\
\hline $\begin{array}{c}\text { Fixed Dollar } \\
\text { Exchange Rate }\end{array}$ & Yes & Determinant & $\begin{array}{c}\text { Reflects productivity } \\
\text { growth in tradables }\end{array}$ \\
\hline $\begin{array}{c}\text { Floating } \\
\text { Exchange Rate }\end{array}$ & No & Indeterminant & $?$ \\
\hline
\end{tabular}

Under a fixed dollar exchange rate, the system converges to relative purchasing power parity (PPP): the rate of inflation in tradables in the peripheral country converges to that in the center country. Subject to the fixed exchange rate constraint, wage bargaining is determinant in the sense that employers bid up money wages to fully reflect the growth of labor productivity in the rapidly growing export sector. International competitiveness is balanced.

Under a floating rate that moves randomly or is hectored into appreciating as with the Japanese yen from 1971 to 1995, bargaining over money wage growth becomes indeterminant. Because risk-averse employers can no longer judge the future course of the (erratically appreciating) exchange rate, they hesitate to bid money wages up by the full amount of productivity growth in the tradables sector. This could be characterized as a negative risk premium in wage bargaining that parallels the negative risk premium in domestic interest rates arising out of fear of appreciation, which has driven short-term interest rates in Japan to zero (McKinnon 2005, Chapter 4). When full scale deflation sets in, money wage growth can also approach zero but, unlike interest rates, could even become negative ${ }^{6}$.

External pressure aside, the weakest link in the current East Asian monetary cum exchange rate system still seems to be Japan. The yen/dollar rate has not been credibly fixed within a narrow range despite massive interventions by the Bank of Japan to prevent the yen from appreciating. The fear of future yen appreciation and further deflation is still rife-and money wages are not adjusting properly. So the first order of business is for the Bank of Japan is to come up with a more credible dollar fix for the yen that would better stabilize intra East Asian exchange rates while ameliorating deflationary fears in Japan itself (McKinnon 2005, McKinnon and Ohno 1997).

However, China now faces more external pressure to appreciate, and the threat of trade sanctions if it does not-much like the "Japan bashing" of the 1970s to the

6 I am greatly indebted to Ms Hong Qiao for pointing out this interesting parallel between a negative foreign exchange risk premium in domestic interest rates and in bargaining over growth in domestic money wages. 
mid 1990s. The potential threat from being pushed into continual currency appreciation, as did Japan after 1971, is a consequent slowdown in China's economic growth and eventually outright deflation.

\section{Limited Foreign Exchange Flexibility for China}

Partly responding to foreign pressure but also because China could benefit from a more open foreign exchange market with decentralized transacting, it is important to pin down what the Chinese government should mean by greater foreign exchange "flexibility". This involves both the pace of liberalizing and rationalizing of capital controls (relaxing administrative constraints on foreign exchange transacting) and the optimal degree of flexibility in the exchange rate itself. Let us discuss each in turn.

In one respect China has been, and remains, very open to foreign capital flows. Inward foreign direct investment (FDI) at over US\$40 billion per year since 2000 has been higher than China's multilateral trade surplus of about 3 percent of GDP. FDI has been an important vehicle for introducing the modern technology underlying China's rapid industrial transformation. It has also been a major contributor to the buildup of China's liquid dollar assets, both held privately and increasingly as official exchange reserves-about US\$660 billion as of March 2005. And outward FDI may be beginning in a significant way, as with Lenovo's purchase of IBM's PC division in 2005, and with large numbers of less publicized investments in African infrastucture projects.

However, there are two distortions in official Chinese policy that unduly amplify the financial magnitudes of inward FDI. First, the tax treatment of foreigners investing in China, particularly in special economic zones, is still more favorable than that accorded domestic investment—although much equalization has occurred. While entirely rational at the beginning of China's opening to international trade in the 1980s, such favoritism for foreign FDI is now counterproductive for encouraging domestic entrepreneurship. The second distortion is to limit foreign firms borrowing from domestic Chinese banks to help fund their operations in China. China wants and needs foreign technical expertise, but with its domestic high domestic saving, it does not need foreign finance. Thus allowing foreign firms to borrow domestically would reduce unwanted financial inflows.

In foreign trade more generally, China has followed, and is following, the optimal order of (gradual) economic liberalization (McKinnon 1993). In the mid 1990s, China consolidated its exchange rate system and achieved full current account convertibility for the renminbi in the sense of satisfying the IMF's Article VIII. In the new millennium, China is rapidly satisfying its WTO obligations by eliminating quota restrictions and drastically cutting tariffs. On capital account, it has liberalized 
relatively illiquid FDI flows before eliminating restrictions on shorter term and more liquid financial flows. All this is according to what is now received textbook theory.

But this last stage, that of liberalizing liquid international financial flows, which can all too easily become "hot" money, is best done very carefully in conjunction with an appropriate regulatory framework - or not at all. The most important principle is to contain (latent) moral hazard in financial institutions, implicitly or explicitly insured by the Chinese government, by limiting their ability to assume risk. In particular, undue foreign exchange exposure in banks and other financial institutions can imperil both themselves and the economy. And foreign financial institutions should always be subject to the same stringent regulatory constraints as domestic ones.

What is the best way to proceed with this delicate last stage in the liberalization process? One way is to assign foreign exchange trading exclusively to authorized banks that must keep their exposure in any foreign currency against renminbi within well defined limits. The State Administration for Foreign Exchange (SAFE) would then continuously monitor the net foreign exchange positions of these authorized banks relative to their capital positions. Only after this interbank foreign exchange market between renminbi and dollars is well established would further liberalization be considered. For example, free foreign exchange trading between major foreign currencies, such as yen against euros, would remain prohibited until a later stage.

Assuming that these prudential regulatory restraints are in place, what should be the range of variation of the yuan/dollar rate itself? In the 1960s during the old Bretton Woods system of fixed dollar parities for Western European countries and Japan, market rates varied within a two percent band around their central rates. Indeed, the foreign exchange margins (one percent on either side of the official parity rate) were officially announced and corresponded to Article IV of the original IMF articles of Agreement. On most trading days, their central banks did not have to intervene and all the clearing of international payments devolved to the authorized commercial banks. But the system was punctuated by occasional crises when official intervention became necessary.

In China today, allowing a similar two-percent band around the central rate of 8.28 yuan per dollar, within which the market rate could fluctuate freely daily or weekly, would efficiently decentralize the foreign exchange market. Indeed, as capital controls are replaced by careful prudential regulation over the net foreign exchange exposures of authorized commercial banks, a widening of the band to, say, 1 percent on either side of the "parity" rate of 8.28 yuan per dollar would make the foreign exchange market more flexible. The current margins are only about 0.3 percent on either side of 8.28 , and unduly limit the private profitability of foreign exchange transacting. 
If the two-percent band is fully credible, in non-crisis periods, the Peoples Bank of China need seldom intervene to maintain it. Thus having the PBC officially announce what the band limits are reinforces regressive expectations: any deviation of the market rate away from 8.28 is expected to be followed by a move back toward 8.28. When the rate moved toward the top of the band, say, 8.4 yuan/dollar, then authorized banks would voluntarily intervene to drive it back down. When these banks know that the PBC is prepared to intervene decisively at either the upper or lower boundaries of the band, they will act as dealers (stabilizing speculators) to nudge the rate toward the middle of the band-without the PBC actually intervening. This ensures that the PBC need not itself intervene much in practice. Then, the clearing of most international payments would devolve from the People's Bank of China (PBC) to the commercial banks or other authorized financial institutions. Subject to constraints on their net foreign exchange position, they would be free to make hedging markets in foreign exchange futures and options for their nonblank customers.

However, if there is a crisis, as when foreigners are put heavy political pressure on China to appreciate leading to hot money inflows, then the PBC has little choice but to intervene by however much is necessary to preserve the central rate.

Changes in the market exchange rate within such a narrow band would not significantly affect-or be intended to affect—a country's competitiveness in international markets for goods or services. It is simply a device for providing flexibility in decentralizing the foreign exchange market. As discussed in Section II above, under a securely fixed central exchange rate, high growth in domestic money wages-reflecting China's very high growth in labor productivity-would remain the dominant mechanism for balancing international competitiveness.

\section{References}

Bergsten, C. F. (2005), and the Institute for International Economics, The United States and the World Economy, Institute for International Economics, Washington D.C.

Bernanke, B. (2005), The Global Saving Glut and the U.S. Current Account Deficit, At the Sandridge Lecture, Virginia Association of Economics, Richmond, Virginia.

Fernholz, R. (2004), China, Japan, and Maintaining International Competitive Balance under a Fixed Exchange Rate Senior Honors Thesis, Stanford University.

Lindbeck, A. (1979), Inflation and Unemployment in Open Economies, Amsterdam, North Holland. 
McKinnon, R. (1993), The Order of Economic Liberalization: Financial Control in the Transition to a Market Economy, Johns Hopkins University Press, $2^{\text {nd }}$ Edition, Translations: Chinese, Romanian, and Arabic (1995).

McKinnon, R. and K. Ohno (1997), Dollar and Yen: Resolving Economic Conflict between the United States and Japan MIT Press, (Translations: Japanese 1998, Chinese 1999).

McKinnon, R. (2005), Exchange Rates under the East Asian Dollar Standard: Living with Conflicted Virtue MIT Press, (Translations: Chinese 2005, Japanese forthcoming 2007).

Zhang, X. and K.-Y. Tan (2004), "Blunt to Sharpened Razor: Incremental Reform and Distortions in the Product and Capital Markets in China”, International Food Policy Research Institute, DSGD Discussion Paper \#13. 